\title{
Early productivity of binary mixtures and single grass species
}

\author{
F.J. PARRY', R.J. LUCAS and B.A. MCKENZIE \\ Plant Science Department, PO Box 84, Lincoln University, Canterbury
}

1 R. D. Hikuai. via Thames

\section{Abstract}

An experiment was conducted on a fertile Walcanui silt loam in 1991/92 to examine the productivity of 4 perennial pasture grass species, Grasslands Roa tall fescue (Festuca arundinacea), Grasslands Marsden hybrid tyegrass (Lolium perenne $x$ Lolium hybridum), Grasslands Maru phalaris (Phalaris aquatica), Grasslands Wana cocksfoot (Dactylis glomerata), and 2 binary mixtures, tall fescue plus cocksfoot and phalaris plus cocksfoot. Between July 1991 and September 1992 the highest production came from phalaris plus cocksfoot at 19.05 t DM/ha. Hybrid ryegrass, phalaris, tall fescue plus cocksfoot, cocksfoot, and tall fescue produced 17.44, 17.13, 16.96, 14.17, and 13.13 t DM/ha respectively. The botanical composition of both mixtures averaged equal proportions of the sown species. The proportion of cocksfoot increased over the summer period then declined for the following autumn/winter period. The experiment shows that simple pasture grass mixtures may be highly productive. These findings support-the-increasing-farmer practice of sowng some pasture grasses in simple mixtures.

Keywords: binary mixture, botanical composition, Ductylis glomerutu, dry matter production, Festucu arundinuceu, Lolium perenne $\boldsymbol{x}$ Lolium hybridum, pasture mixtures, Phaluris aquatica, seasonal production

\section{Introduction}

Ryegrass (Lolium perenne)/white clover (Trifolium repens) is the most commonly sown pasture mixture throughout New Zealand. However, where summer dry conditions prevail and fertility may be limiting, production from these pastures declines with time (Macfarlane 1990). High endophyte ryegrass may also cause ryegrass staggers, and low endophyte ryegrass may be damaged by Argentine stem weevil (Listronotus bonariensis) (Fletcher $\boldsymbol{e t}$ al. 1990). Ryegrass and white clover are also very susceptible to grass grub (Costelytra zealandica) damage (Chapman 1990).

Many dryland farmers have become aware of alternative pasture grass species which avoid the problems of ryegrass, and are productive in dryland environments. Three perennial grasses which may be sown instead of ryegrass are tall fescue (Festuca arundinacea), phalaris (Phalaris aquatica), and cocksfoot (Dactylis glomerata). These species have been evaluated when sown alone: tall fescue (Brock 1983), phalaris (Stevens et al. 1989). cocksfoot (Barker et al. 1985). Some work has been done on the performance of pasture mixtures using these species (Moloney et al. 1993; Milne et al. 1993). They have shown there may be advantages in sowing grasses other than ryegrass in mixtures. Pasture mixtures may provide additional productivity over pure swards and other possible benefits as outlined by Charlton (1991). Trenbath (1974) questions whether there are many cases where mixtures give a substantial advantage relative to the highest producing pure component (over-yielding). The ability to 'overyield' is the real test of mixture productivity.

The aim of this experiment was to study the productivity and botanical composition of two binary grass mixtures compared to either pure swards of the species in the mixtures or ryegrass.

\section{$M$ aterials and-methods}

The productivity of 6 pasture grass treatments were measured for 14 months following a S-month establishment period. The treatments were: Grasslands Roa tall fescue, Grasslands Marsden hybrid ryegrass (Lolium perenne x Lolium hybridum) with $90 \%$ ryegrass endophyte, Grasslands Maru phalaris, Grasslands Wana cocksfoot, and 2 binary mixtures, tall fescue plus cocksfoot and phalaris plus cocksfoot. The experiment was a randomised block design with 4 replicates, the treatments were hand broadcast on $6 \times 1.66 \mathrm{~m}$ plots on 6-7 March 1991. The pure treatments were sown at rates of 600 viable seed $/ \mathrm{m}^{2}$, binary mixtures were sown at rates of 300 viable seeds $/ \mathrm{m}^{2}$ for each component. Seedling establishment (seedlings $/ \mathrm{m}^{2}$ ) at the end of 2 months of establishment were: 390 (tall fescue), 430 (ryegrass), 300 (phalaris), 256 (cocksfoot), 380 (tall fescue [235] plus cocksfoot [145]), and 215 (phalaris [ 155] plus cocksfoot [60]). The site was a fertile Wakanui silt loam soil which had been used for various research purposes. Clovers were not sown in this experiment to avoid the confounding effect of grass/ legume interactions. MCPA was used to eliminate dicotyledon species during the establishment period. Poa annua was a significant contaminant for 7 months 
after establishment. Fertiliser was applied on 14 October 1991 (50 kg nitrogen $(\mathrm{N}) / \mathrm{ha}$ as calcium ammonium nitrate, and on the 17 January $1992(63 \mathrm{~kg} \mathrm{~N} / \mathrm{ha}, 40 \mathrm{~kg}$ $\mathrm{P} / \mathrm{ha}, 112 \mathrm{~kg} \mathrm{~K} / \mathrm{ha}, 43 \mathrm{~kg} \mathrm{~S} / \mathrm{ha}$ as nitrophoska blue and ammonium sulphate. Irrigation $(22 \mathrm{~mm})$ was applied on 12-14 March 1991 to maintain adequate moisture during establishment, and $165 \mathrm{~mm}$ was applied on 2431 January 1992 to bring the soil to field capacity for a water use substudy which was conducted concurrently (Parry 1994; Parry et.al. 1992).

After an establishment period of 5 months an establishment harvest was taken on the 9 July 1991, using a reel mower. This was followed by 7 production harvests from 11 September 1991 to 2 September 1992 also using reel mowers. There were uneven periods between harvests because of constraints imposed by the water use substudy and lack of pasture growth during winter. Botanical composition was determined by herbage dissection on 5 occasions from samples hand

Table 1 Weather data for Lincoln from March, 1991 until August 1992. Long term means $(10,10$, and 50 years respectively) in parentheses.

\begin{tabular}{lcccccc}
\hline & Autumn' & Winter2 & \multicolumn{2}{c}{ Spring } & Summer A u t u m n & Sumter \\
& 91 & 91 & 91 & $91 / 92$ & 92 & 92 \\
\hline Air Temp & 12.6 & 6.3 & 10.6 & 15.1 & 10.5 & 6.1 \\
$\left({ }^{\circ} \mathrm{C}\right)$ & $(11.8)$ & $(6.2)$ & $(11.6)$ & $(16.0)$ & $(11.8)$ & $(6.2)$ \\
$10 \mathrm{Cm}$ Soil Temp & 9.7 & 2.7 & 9.6 & 14.4 & 6.2 & 2.5 \\
$\left({ }^{\circ} \mathrm{C}\right)$ & $(10.9)$ & $(4.6)$ & $(10.6)$ & $(16.6)$ & $(10.9)$ & $(4.6)$ \\
Rainfall & 150 & 160 & 102 & 143 & 164 & 207 \\
$(\mathrm{~mm} /$ season) & $(184)$ & $(191)$ & $(149)$ & $(171)$ & $(184)$ & $(191)$ \\
\hline
\end{tabular}

$1=$ March, April, May $2=$ June, July, August $3=$ September, October, November $4=$ December, January, February.

Figure 1 (a) and (b) Replacement series diagrams showing the total yield and average botanical composition of ' 2 pasture grass binary mixtures and their respective pure swards. Ia, tall fescue plus cocksfoot $\mathrm{lb}$, phalaris plus cocksfoot (weed data not shown). Measured over 422 days (Isd 5\% $=2.45 \mathrm{t} \mathrm{DM} / \mathrm{ha})$. Total production $(\boldsymbol{\bullet})$, tall fescue $(\boldsymbol{\Lambda})$, phalaris $(\boldsymbol{})$, and cocksfoot (廿).

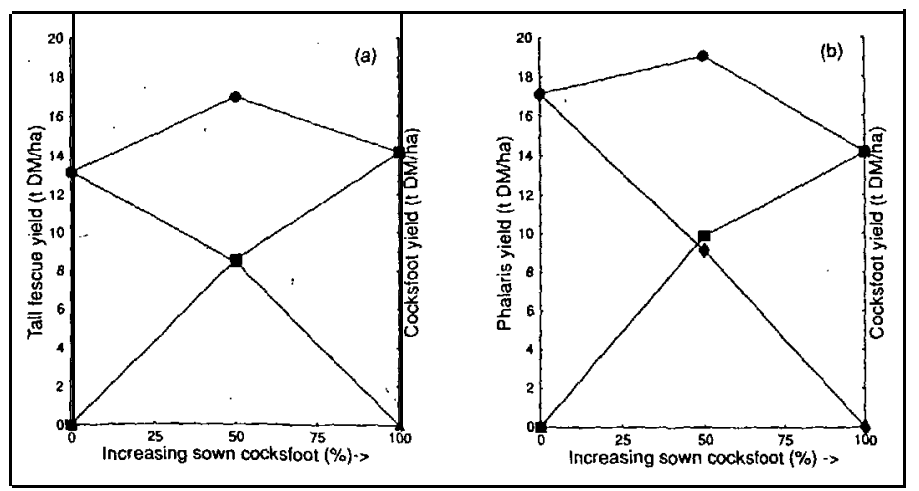

cut from the swards to a height of $40 \mathrm{~mm}$. Climate measurements came from the Lincoln meterological

All results were analysed using analysis of variance and where differences were significant lsd $\quad(P=0.05)$ values were calculated.

\section{Results}

Climate

Mean air and $10 \mathrm{~cm}$ soil temperatures were lower than except for winter 1992. Irrigation approximately doubled

Total production and botanical composition

There was a $5.92 \mathrm{t} \mathrm{DM/ha}$ range in total dry matter production over the 14-month production period, the highest production was $19.05 \mathrm{t}$ DM/ha from phalaris plus cocksfoot. Hybrid ryegrass, phalaris, tall fescue plus cocksfoot, cocksfoot, and tall fescue produced $17.44,17.13,16.96,14.17$, and $13.13 \mathrm{t}$ DM/ha respectively. Phalaris plus cocksfoot, hybrid ryegrass, phalaris, and tall fescue plus cocksfoot were not significantly different from each other in total production, but all four treatments were significantly greater than cocksfoot and tall fescue.

Tall fescue plus cocksfoot produced significantly greater amounts of herbage than either tall fescue or cocksfoot sown alone (Figure la).

The average botanical composition of tall fescue plus cocksfoot and phalaris plus cocksfoot (excluding 2.3 and $0.2 \%$ weeds respectively) were $\mathbf{5 0 /}$ 50 and $48 / 52 \%$ (Figure la \& b).

\section{Seasonal production}

The relative production of the six pasture treatments varied throughout the 14-month period (Figure 2). Hybrid ryegrass had the greatest production in early and late spring. Tall fescue produced the greatest amount of dry matter in mid spring. Tall fescue plus cocksfoot was' the highest producing treatment in an early summer harvest (not significant), while phalaris had the highest production in mid summer. The two binary, mixes had the highest production rates in late summer/autumn 
although the differences between treatments were not significant. Phalaris was the highest producer for the winter 1992 period.

Botanical composition over time The botanical composition of the two binary mixtures changed over the year (Figure $3 \mathrm{a}$ and $\mathrm{b}$ ). Cocksfoot increased in percentage from a low level at the establishment harvest, to be dominant in terms of dry matter for the harvest period ended 7 April 1992. Both tall fescue and phalaris produced more than cocksfoot during winter.

\section{Discussion}

The production rate of the six treatments varied considerably during the experimental period, reflecting the influence of the seasons, the differing establishment speeds of the species, and the influence of the uneven harvest periods on the treatments.

Both mixtures produced more dry matter than their respective pure swards. Tall fescue plus cocksfoot showed overyielding as it had significantly greater production than either tall fescue and cocksfoot grown

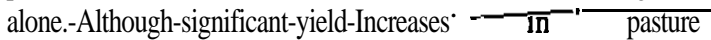
mixtures over pure swards have rarely been reported, Whittington \& O'Brien (1968) demonstrated overyielding with mixtures of ryegrass and meadow fescue. The two mixtures in this experiment had their highest production during the 82-day period from January to April of the six treatments although this superiority was not statistically significant it suggested that the mixtures were able to exploit the environment most effectively during this period.

The replacement series diagrams (Figure $1 \mathrm{a}$ and b) show that the two mixtures had maximum production when the sown grass percentage was on or near 50/ $50 \%$, tall fescue plus cocksfoot showing a statistically significant yield advantage over its pure components and phalaris plus cocksfoot nearly achieving this also. Observations during the second year indicated that cocksfoot continued to increase in percentage botanical composition compared with the year of measurement and this led to much greater cocksfoot cover in the mixed swards at the end of the second year. Difficulty in maintaining some mixtures over time may therefore limit their advantage.

An increase in percentage cocksfoot in mixtures
Figure 3 (a) and (b) The botanical composition of 2 binary mixtures from July 1991 until September 1992. 3a, tall fescue plus cocksfoot; 3 b, phalaris plus cocksfoot at 5 harvest dates weeds; cocksfoot; tall fescue; 0 phalaris). Error bars are standard error of the mean

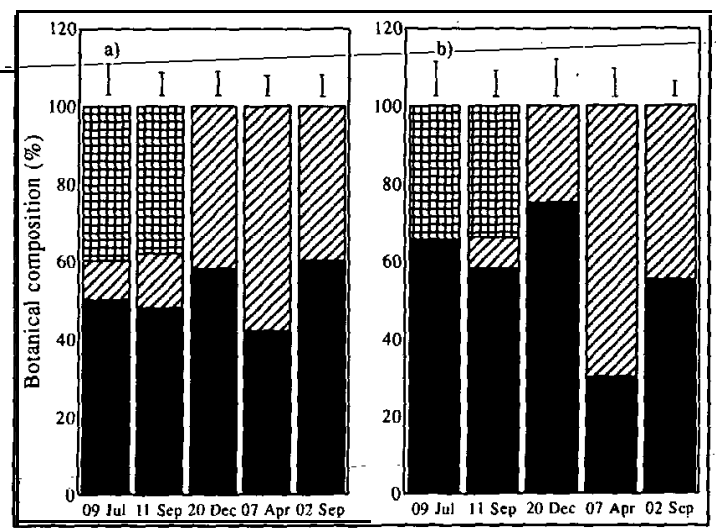

during the summer-early autumn period and its subsequent decline over the autumn-winter period indicated complementary seasonal growth between the two grass components in both mixtures. Trenbath (1974), in a major review of research on the biomass productivity of mixtures, highlighted 8 possible mechanisms for yield responses. Differing growth patterns was 1 of the proposed mechanisms, and may be a reason for the yield responses shown in this experiment. The other mechanisms discussed were: differing rooting depths, 
nutritional complementation (unlikely in mixtures other than legume/non-legume), enhanced light-use efficiency. enhanced water-use efficiency, allelopathy, lodging escape, and pathogen escape. All of these other mechanisms may also be valid (apart from nutritional complementation) in explaining the yield response of these mixtures. Water-use efficiency varied between the six treatments in a water use substudy carried out during the summer/early autumn period (Parry 1994).

The treatment production totals showed that some pasture grass mixtures and alternative pasture grasses alone can produce equal or greater amounts of dry matter than hybrid ryegrass. which has similar performance to perennial ryegrass (Pennellet al. 1990). These findings are consistent with those of Moloney (1991), who reported that a tall fescue plus cocksfoot pasture outyielded ryegrass by $3.5 \mathrm{t} \mathrm{DM/ha/yr} \mathrm{in}$ Atiamuri and $1.4 \mathrm{t} \mathrm{DM} / \mathrm{ha} / \mathrm{yr}$ at Castlepoint. The findings of this experiment support the practice of sowing some pasture grasses in binary mixtures. Further work is necessary to examine the effects of adding a legume into these mixtures, and to monitor their botanical composition over several years.

\section{Conclusions}

1. Some binary mixtures and pure swards had equal or greater production than hybrid ryegrass.

2. During the first year when component species were present in approximately equal amounts, phalaris plus cocksfoot and tall fescue plus cocksfoot mixtures had complementary seasonal growth which appeared to contribute to the mixtures yielding more than the pure swards.

3. Sowing alternative pasture grasses in simple mixtures can be suggested as a possible way to increase pasture production.

\section{REFERENCES}

Barker, D.J.; Lancashire, J.A.; Meurk. C. 1985. 'Grasslands Wana' cocksfoot- An improved grass suitable for hill country. Proceedings of the New Zealand Grassland Association 46: 167-172.

Brock, J.L. 1983. 'Grasslands Roa' tall fescue: A review. Proceedings of the New Zealand. Grassland Association 44: 74-80.

Chapman, R.B. 1990. Insect pests. p448-467 In. Langer, R.H.M.(ed.). Pastures: their ecology and management. Oxford University Press; Auckland.
Chariton, J.F.L. 1991. Some basic concepts of pasture seed mixtures for New Zealand farms. Proceedings of the New 'Zealand GrasslandAssociation 53: 37. 40.

Fletcher, L.R.; Hoglund, J.H.; Sutherland, B.L. 1990. Tbe impact of Acremonium endophytes in New Zealand, past, present and future. Proceedings of the New Zealand Grassland Association 52: 227. 235.

Macfarlane. A.W. 1990. Field experience with new pasture cultivars in Canterbury. Proceedings of the New Zealand Grassland Association 52: 139- 143.

Milne, G.D.; Moloney, S.C.; Smith, D.R. 1993. Demonstration of dryland species on 90 east coast North Island farms. Proceedings of the New Zealand Grassland Association 55: 39-44.

Moloney, S.C. 1991. Performance of tall fescue, cocksfoot and phalaris based pastures compared with perennial ryegrass, in on-farm trials. Proceedings of the New Zealand Grassland Association 53: 4146.

Moloney, SC.; Lancanshire, J.A.; Barker, D.J. 1993. Introduction, production, and persistence of five grass species in dry hill country 7. Central Plateau, North Island, New Zealand. New Zealand Journal of Agricultural Research 36: 49-59.

Parry, F.J. 1994. Productivity and water use of seven pasture grasses when sown alone and in binary mixtures. M.Appl.Sc, thesis, Lincoln University, Canterbury, New Zealand.

Parry, F.J. 1992. Productivity and water use of five pasture grasses in Canterbury. Proceeding of the New Zealand Grassland Association 54: 135- 138.

Pennell, C.G.L.; Easton, H.S.; Goold, G.J.; Hay, R.J.M.; Hickey, M.J.; Hoglund, J.H.; Lyons, T.B.; McCallum, D.A.; Paewai, H.R.T.; Stevens,D.R.; Thompson, N.A.; Woods, P.W. 1990. 'Grasslands Pacific' perennial ryegrass: performance at several sites. Proceedings of the New Zealand Grassland Association 52: 151-155.

Stevens, D.R.; Turner, D.J.; Barker, D.J.; Moloney, S. 1989. 'Grasslands Maru' Phalaris: Productive and persistent in hill country. Proceedings of the New Zealand Grassland Association 50: 23 1-236.

Trenbath, B.R. 1974. Biomass productivity of mixtures. Advances in agronomy 26: 177-209.

Wbittington, W.J; O'Brien, T.A. 1968. A comparison of yields from plots sown with a single species or a mixture of grass species. Journal of applied ecology 5: 209-213. 